\title{
ASSESSMENT OF THE EFFICIENCY OF SEWAGE TREATMENT PLANTS: A COMPARATIVE STUDY BETWEEN NAGASANDRA AND MAILASANDRA SEWAGE TREATMENT PLANTS
}

\author{
Ravi Kumar, P., ${ }^{*}$ Liza Britta Pinto, Somashekar, R.K. \\ Department of Environmental Science, Bangalore University, Bangalore -560056. \\ *Corresponding author: prakruthiravi@gmail.com \\ Received 24 June, 2009; Revised 26 February, 2010
}

\begin{abstract}
Bangalore city hosts two Urban Wastewater Treatment Plants (UWTPs) towards the periphery of Vrishabhavathi valley, located in Nellakedaranahalli village of Nagasandra and Mailasandra Village, Karnataka, India. These plants are designed and constructed with an aim to manage wastewater so as to minimize and/or remove organic matter, solids, nutrients, disease-causing organisms and other pollutants, before it reenters a water body. It was revealed from the performance study that efficiency of the two treatment plants was poor with respect to removal of total dissolved solids in contrast to the removal/reduction in other parameters like total suspended solids, BOD and COD. In Mailasandra STP, TDS, TSS, BOD, and COD removal efficiency was 20.01, 94.51, 94.98 and $76.26 \%$ and respectively, while in Nagasandra STP, TDS, TSS, BOD, and COD removal efficiency was $28.45,99.0,97.6$ and $91.60 \%$ respectively. The order of reduction efficiency was TDS < COD < TSS < BOD and TDS < COD < BOD < TSS respectively in Mailasandra and Nagasandra STPs. Additionally, the problems associated with the operation and maintenance of wastewater treatment plants is discussed.
\end{abstract}

Keywords: Total dissolved solids, Chemical oxygen demand, Biochemical oxygen demand, Aeration tank, Mixed liquor suspended solids, Sludge volume index

\section{INTRODUCTION}

We are silently but surely heading towards "water shock" which will dwarf any oil crisis, because in the last two decades for the first time in the human history more water is being taken out across the globe than what Nature is putting in. Wastewater is used water, comprising of substances such as human waste, food scraps, oils, soaps, chemicals, domestic wastes. Businesses and industries also contribute their share of used water/waste waters in addition to storm runoff burdened with harmful substances via run off from roads, parking lots and rooftops and this can harm our fresh water systems. Even though, nature has an amazing ability to cope with certain amounts of contaminants, there is a necessity to treat the billion gallons of wastewater and sewage generated daily by homes, industries, and business establishments before releasing it back to the environment.

In Venuzuela, 97 percent of the country's sewage is being discharged raw into the environment (Anonymous, 1998) while, most of sub-Saharan Africa is without wastewater treatment. In a relatively developed Middle Eastern country such as Iran, totally untreated sewage has been injected into the Tehran city's groundwater (Tajrishy and Abrishamchi, 2005). As such urban drainage system should also be considered as an important infrastructure in removing both wastewater and rainwater from city to prevent unhygienic conditions and to avoid damage from flooding (Karrman, 2001 and Erbe et al., 2002). 
Wastewater or sewage treatment is one such alternative, wherein many processes are designed and operated in order to mimic the natural treatment processes to reduce pollutant load to a level that nature can handle. In this regard, special attention is necessary to assess the environmental impacts of existing wastewater treatment facilities (Jamrah, 1999). A detailed characterization of the incoming wastewater and a performance evaluation was carried out for the domestic wastewater treatment plant of Erzincan City, Latin America (Nuhoglu et al., 2004), wherein 15\% of collected wastewater passes through treatment plants (with varying levels of actual treatment). Evaluation of municipal wastewater treatment plants with different technologies at Las Rozas, Madrid, Spain (Colmenarejo et al., 2006) and characterization of the influent and the effluent wastewater for performance evaluation at Sivas, Turkey (Coskuner and Ozdemir, 1991) are some of the important contributions.

\section{STUDY AREA}

In Bangalore, Karnataka, India the Bangalore Water Supply and Sewage Board (BWSSB) oversees the task of two essential amenities the community desires such as supply of safe water and maintenance of hygienic sanitation facilities. As a consequence of natural topography of the city, the sewage generated from the city is easily drained to the four main valleys namely the Koramangala, Challaghata, Vrishabhavati and the Hebbal valleys (Fig 1). Treatment plants are designed and constructed for all the four main valleys, besides some smaller treatment plants, that treat wastewater to meet the standards for discharging treated wastewater (effluent) into inland surface water.

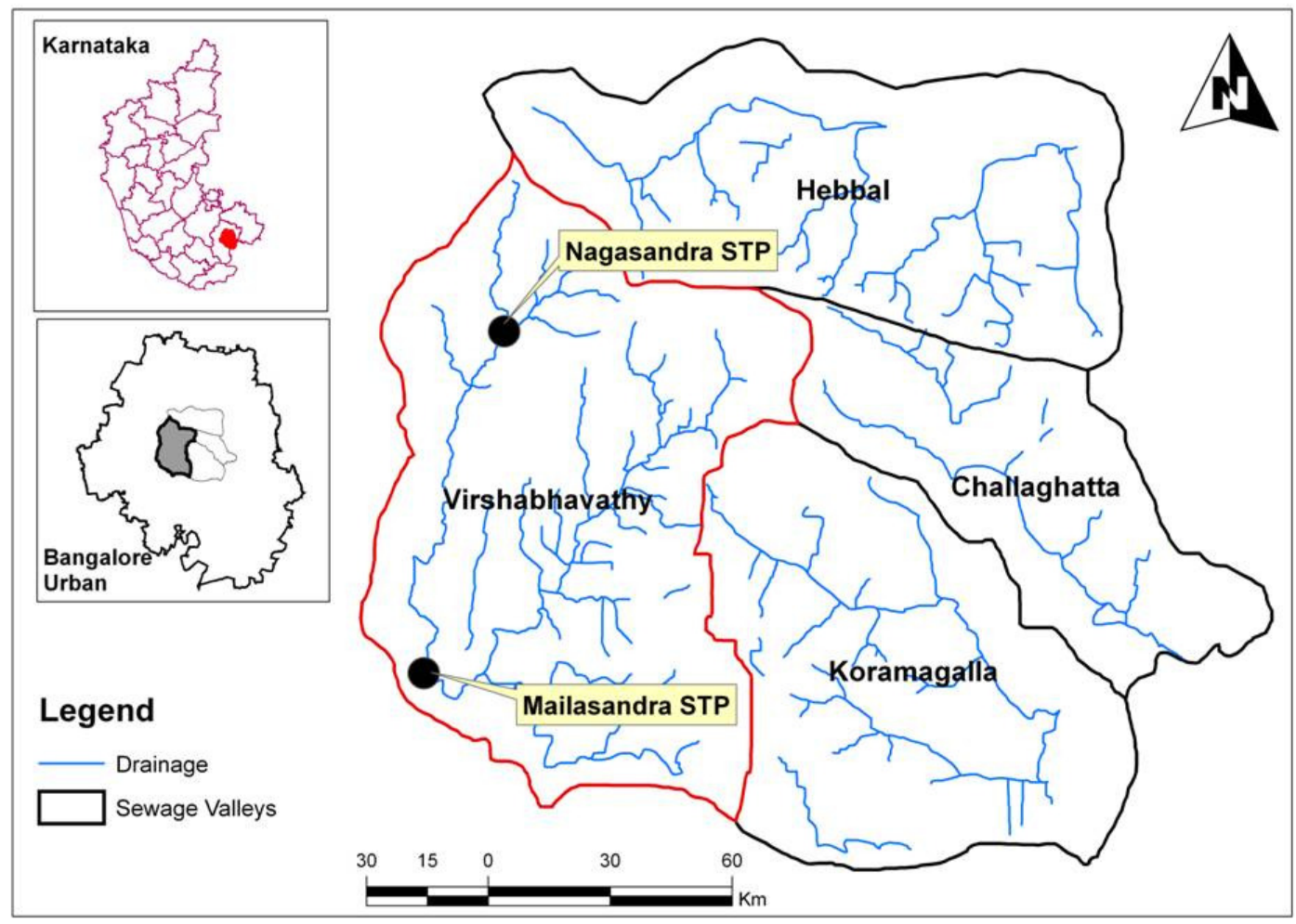

Fig 1. Location Map showing Sewage Treatment Plants 
The study area covers two Urban Wastewater Treatment Plants (UWTPs) namely, Nagasandra and Mailasandra Sewage Treatment Plants situated in Bangalore city (Fig: 1 \& 2) located respectively at Nellakedaranahalli village in Nagasandra and at Mailasandra village, ten $\mathrm{km}$ from city railway station in southwest direction on Mysore road. The STP provided at Nagasandra handles an average design flow of 20 MLD followed by minimum and peak flow of 10 and 40 MLD respectively. In contrast, the STP at Mailasandra is designed to handle an average design flow of 75 MLD with minimum and peak flows of 45 and 155 MLD respectively. The STP aimed at collecting the raw sewage and treat before discharging into inland surface water.

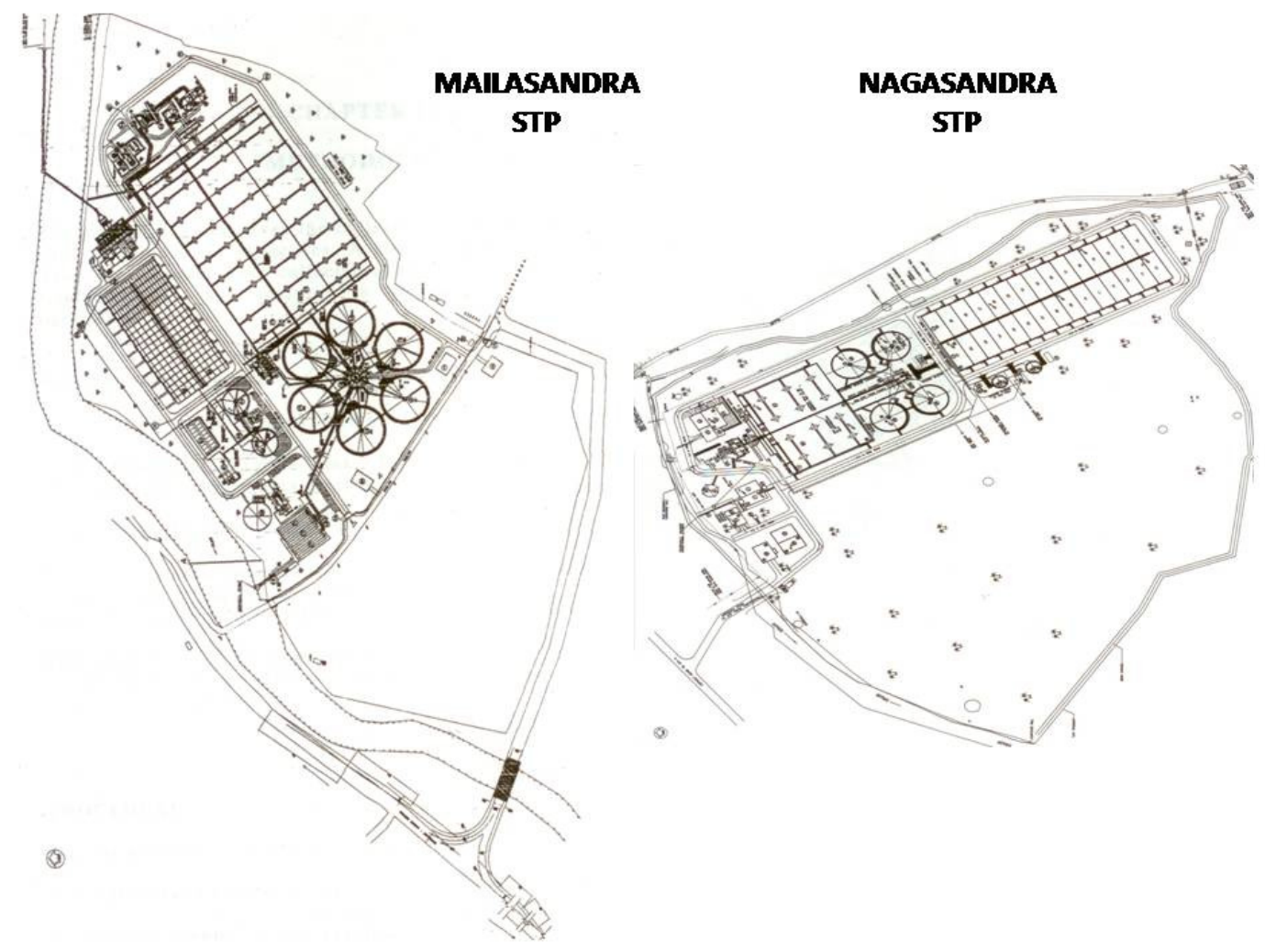

Fig 2. Site Layout Map of Mailasandra and Nagasandra Treatment Plants

This paper describes the performance of the sewage treatment plants in terms of wastewater characterization to derive a comparative account between the pollution load before and after the treatment processes, besides, discerning their efficiency.

\section{MATERIALS AND METHODS}

The experimental method involved the collection of composite samples in clean plastic containers of 5 liter capacity at three different units of the treatment plant, namely, a) Influent to the treatment plant, b) Effluent of aeration tank (considered for the influent of secondary clarifiers) and c) final effluent from secondary clarifiers for seven days.

The samples were analyzed using the Standard Methods (APHA, AWWA, and WCF 1998). The primary parameters included $\mathrm{pH}$, total dissolved solids (TDS), total suspended 
solids (TSS), Dissolved oxygen (DO), 5-day biochemical oxygen demand $\left(\mathrm{BOD}_{(5)}\right)$, chemical oxygen demand (COD), chlorides and sulphates, the ratio of $\mathrm{COD}$ to $\mathrm{BOD}_{(5)}$; while secondary parameters are MLSS and SVI, covering physical, chemical, and biochemical properties of the wastewater. The $\mathrm{pH}$ was estimated by using $\mathrm{pH}$ meter, while sulphates gravimetrically.

Mixed Liquor Suspended Solids (MLSS, mg/L) was calculated by drying the settleable solids, at the bottom of Imhoff cones in a litre of sample taken. The settleable solids were dried in oven and weighed.

Sludge Volume Index (SVI): $1000 \mathrm{ml}$ sample colleted from Aeration tank was allowed to settle for 30 minutes and the amount of sludge settled in jar is given as

$$
\text { SVI }=(\text { Settalability } / \text { MLSS }) \times 1000
$$

The inflow of the sewage into the treatment plant is calculated using the following formula:

$$
Q=2 / 3 \mathrm{~cd} \times \mathrm{L} \times 2 \times \mathrm{g} \times \mathrm{H}^{3 / 2}
$$

Where

$\mathrm{cd}=$ Coefficient of discharge $=0.6$

$\mathrm{L}=$ Length of weir $=15.1 \mathrm{~m}$

$\mathrm{g}=$ Acceleration due to gravity $=2.8 \mathrm{~m} / \mathrm{sec}$.

$\mathrm{H}=$ Head over the rectangular weir.

\section{RESULTS AND DISCUSSION}

Colmenarejo et al., (2006) determined the general efficiency indicator to compare overall performances of the different plants in terms of average TSS, COD, $\mathrm{BOD}_{(5)}$ and ammonia removal efficiencies. Similarly, the efficiency of plants is generally measured in terms of removal of organic matter (CPHEEO, 1993). The $\mathrm{pH}$ directly affects the performance of a secondary treatment process (Metcalf and Eddy, 1991 \& 2003) because the existence of most biological life is dependent upon narrow and critical range of $\mathrm{pH}$. Since, the solids removal is an important measure for the success of a primary treatment unit (McGhee, 1991) and the dissolved solids content of the wastewater is of concern as it affects the reuse of wastewater for agricultural purposes, by decreasing the hydraulic conductivity of irrigated land if the total dissolved solids content in the water exceeds $480 \mathrm{mg} / \mathrm{l}$ (Bouwer, 1978). Also, BOD removal is indicative of the efficiency of biological treatment processes (Sincero and Sincero, 1996), special consideration has been given in the current study to the organic content, characterized by $\mathrm{BOD}_{(5)}$, $\mathrm{COD}$ and the $\mathrm{COD} / \mathrm{BOD}_{(5)}$ ratio. Based on the performance study conducted for different primary and secondary parameters for a period of seven days, a comparative account was drawn on the following:

\section{Characteristics of Waste Water Influent to Inlet of the Treatment Plants}

At Mailasandra STP, at the inlet, the concentration of total dissolved solids, total suspended solids, BOD $_{(5)}$ and COD were $875-1152 \mathrm{mg} / \mathrm{L}, 70-134 \mathrm{mg} / \mathrm{L}, 150-205 \mathrm{mg} / \mathrm{L}$, $356-424 \mathrm{mg} / \mathrm{L}$ respectively, while the average chlorides and sulphates were $150.4 \mathrm{mg} / \mathrm{L}$ and $40.7 \mathrm{mg} / \mathrm{L}$ respectively (Table 1 ). The $\mathrm{pH}$ varied from 7.38 to 7.72 . Similarly, at 
Nagasandra STP, at the inlet, the concentration of total dissolved solids, total suspended solids, $\mathrm{BOD}_{(5)}$ and COD values ranged between $1800-2850 \mathrm{mg} / \mathrm{L}, 300-766 \mathrm{mg} / \mathrm{L}, 255-850$ $\mathrm{mg} / \mathrm{L}, 480-1632 \mathrm{mg} / \mathrm{L}$ respectively. The average Chlorides and Sulphates was $413 \mathrm{mg} / \mathrm{L}$ and $41 \mathrm{mg} / \mathrm{L}$ respectively, while the $\mathrm{pH}$ varied from 7.01 to 7.66 .

Out of seven days of performance study, the highest value of total dissolved solids (1152 $\mathrm{mg} / \mathrm{L})$, total suspended solids $(134 \mathrm{mg} / \mathrm{L}), \mathrm{BOD}_{(5)}(205 \mathrm{mg} / \mathrm{L})$ and COD $(424 \mathrm{mg} / \mathrm{L})$ were noticed on the second day in Mailasandra STP, is attributed to heavy organic and inorganic loading with less liquid content (Table 1). Similarly, the highest total dissolved solids $(2850 \mathrm{mg} / \mathrm{L})$, total suspended solids $(766 \mathrm{mg} / \mathrm{L}), \mathrm{BOD}_{(5)}(850 \mathrm{mg} / \mathrm{L})$ and COD $(1632 \mathrm{mg} / \mathrm{L})$ on fourth day in Nagasandra STP, which is also due to heavy organic and inorganic loading with less amount of water. In both the plants, the DO was "nil" at inlet, stimulated by oxidation of sewage ammonia to nitrates, septic condition, heavy organic loadings.

\section{Characteristics of Wastewater Effluent to Aeration Tank}

The aeration tank in both the treatment plants is considered a most important step in activated sludge process and the priority was intended to increase the dissolved oxygen level of sewage so that the efficient aerobic digestion facilitates decomposition of organic matter. This has to be ensured because of low dissolved oxygen content (nil) in the influent. In Mailsandra and Nagasandra STPs, the DO in aeration tank ranged from 1.8 to $3.2 \mathrm{mg} / \mathrm{L}$ and 1.5 to $3.1 \mathrm{mg} / \mathrm{L}$ respectively, indicating an efficient and satisfactory working. The $\mathrm{pH}$ varied from 7.49 to 7.82 and 7.26 to 7.75 respectively in Mailasandra and Nagasandra STPs (Table 2).

Efficiency of the aeration tank was calculated by considering percentage reduction of BOD. The average influent value of BOD in aeration tank was $173.57 \mathrm{mg} / \mathrm{l}$ while the average effluent value from this tank is $91.72 \mathrm{mg} / \mathrm{L}$ in Mailasandra STP in contrast with average influent BOD of $479.52 \mathrm{mg} / \mathrm{l}$ and that of effluent being $171.47 \mathrm{mg} / \mathrm{L}$ in Nagasandra STP. The percentage removal of BOD in both the treatment plants is $47.16 \%$ and $64.24 \%$ respectively (Fig 3) against the expected value of 70-85\%, illustrating that BOD reduction is little less than the expected. This slight decrease is attributed to the recycling of old sludge that contained fewer microorganisms, besides insufficiency of MLSS for the aerobic digestion of the organic matter. The DO during the aeration was absorbed by the microorganisms due to less availability of fresh organic matter.

The MLSS concentration in the aeration tank ranged between $2810-2950 \mathrm{mg} / \mathrm{L}$ and 2830 $3080 \mathrm{mg} / \mathrm{L}$ in both the treatment plants against the expected concentration of 1500-3000 $\mathrm{mg} / \mathrm{L}$, confirming suitability of secondary clarifier in terms of microbial content.

A SVI value of 100-150 indicates good settling of suspended solids that can be achieved for proper MLSS concentration. The SVI was 40-43 in Mailasandra STP, quite low compared to the expected value, while it was closer to anticipated values in Nagasandra STP (77-95). 


\section{Characteristics of Wastewater Effluent to Secondary Clarifier}

At the secondary clarifier of Mailasandra Treatment plant, the concentration of total dissolved solids, total suspended solids, COD, chlorides and sulphates $680-880 \mathrm{mg} / \mathrm{L}, 2-8$ $\mathrm{mg} / \mathrm{L}, 82.8$ to $106.9 \mathrm{mg} / \mathrm{L}, 138.6$ to $151.3 \mathrm{mg} / \mathrm{L}$ and 32.46 to $38.7 \mathrm{mg} / \mathrm{L}$ respectively. The $\mathrm{pH}$ varied from 7.81 to 8.06. At the secondary clarifier of Nagasandra Treatment plant, total dissolved solids, total suspended solids, COD, chlorides and sulphates were 1350$1700 \mathrm{mg} / \mathrm{L}, 3.3-6.6 \mathrm{mg} / \mathrm{L}, 40-120 \mathrm{mg} / \mathrm{L}, 320-450 \mathrm{mg} / \mathrm{L}$ and $26.39 \mathrm{mg} / \mathrm{L}$ respectively. The $\mathrm{pH}$ varied from 7.49 to 7.80 (Table 3 ).

The BOD ranged from 8.2-9.2 $\mathrm{mg} / \mathrm{L}$ at secondary clarifier of Mailasandra STP with highest BOD on fourth day $(9.2 \mathrm{mg} / \mathrm{L})$ of performance study, while in Nagasandra STP, the BOD ranged from 5.8-19.0 mg/L, again highest on fourth day $(18 \mathrm{mg} / \mathrm{L})$. The efficiency of BOD removal in secondary clarifier is 90.51 and $93.42 \%$ respectively in Mailasandra and Nagasandra treatment plants (Fig 3), confirming efficiency of the secondary clarifier and its suitability to be discharged. The higher DO values of confirmed the above observation.

\section{Overall Efficiency of the Two Treatment Plants}

The overall efficiency of the two treatment plants was calculated by considering the TDS, TSS, COD and BOD of the influent and the final effluent from the secondary clarifier (Fig 4). The reduction in COD is 76.26 and $91.60 \%$ in Mailasandra and Nagasandra STP respectively. Also, a significant variation was found in influent/sewage flow rates between the two treatment plants for the study period of seven days were recorded (Fig 5).

The percentage reduction in total dissolved solids is $20.01 \%$ and $28.48 \%$, respectively, in Mailasandra and Nagasandra STPs, much below the expected removal of $70-80 \%$ indicating poor efficiency in terms of total dissolved solids removal. However, the removal of total suspended solids and BOD was found to be very satisfactory.

The reduction in total suspended solids is $94.51 \%$ and $99 \%$ in Mailasandra and Nagasandra STPs respectively against the expected value of 85-90\%, while the reduction in of BOD is $94.98 \%$ and $97.6 \%$ at Mailasandra and Nagasandra STP respectively against the expected value of $85-90 \%$.

There is usually no correlation between $\mathrm{BOD}_{(5)}$ and COD in wastewater with slowly biodegradable organic suspended solids and in complex waste effluents containing refractory substances (Eckenfelder, 1989). Hence, treated effluents may exert virtually no $\mathrm{BOD}_{(5)}$ and yet exhibit a substantial COD. Since, the COD represents virtually all organic matter, either partially degradable or non-biodegradable and $\mathrm{BOD}_{(5)}$ the total oxygen demand, it is necessary to develop relationship between $\mathrm{BOD}_{(5)}$ and COD. Accordingly, the average influent and effluent COD/BOD5 ratios for the treatment plants were calculated and it is observed that the $\mathrm{COD} / \mathrm{BOD}_{(5)}$ ratio frequently varied for effluents compared to untreated wastes.

The influent wastewater of Mailasandra and Nagasandra STP exhibited a ratio ranging from about 1.87 to 2.44 and 0.923 to 1.92 respectively and the values are comparable to those presented by Metcalf and Eddy (1991 \& 2003). The typical COD/BOD (5) $_{\text {ratio of }}$ domestic wastewaters is usually in the range 1.25 to 2.5 . However, for treated effluents, it 
ranged from 9.767 to 11.62 and 3.357 to 9.655 respectively for Mailasandra and Nagasandra STP (Tables 4). This indicates relatively higher proportion of the nonbiodegradable content in treated effluent than raw wastewater. As a consequence, the efficiency of $\mathrm{BOD}_{(5)}$ removal is higher than that of COD removal.

\section{CONCLUSION}

The performance studies on the Mailasandra and Nagasandra Sewage Treatment Plants located on the periphery of Vrishabhavathi valley conducted for a period of seven days, indicated a positive efficiency of the system. The overall efficiency is in the order TDS < COD $<$ TSS < BOD in Mailasandra STP while in Nagasandra STP, it is TDS < COD < BOD $<$ TSS. The performance of the aeration tank and secondary clarifier was nearly up to the mark in both the cases. In order to achieve better performance, fresh sludge with higher microorganism populations should be recycled and the aerators must be operated continuously. The treated effluent can be safely discharged into streams, rivers, bay, lagoon or wetland, or it can be reused for irrigation of a golf course, green way, park or for groundwater recharge as opined by (Fatta et al., 2005).

\section{REFERENCES}

1. Anonymous. 1998. Appropriate Technology for Sewage Pollution Control in the Wider Caribbean Region, Caribbean Environment Programme Technical Report No. 40.

2. APHA-AWWA-WEF. 1998. Standard methods for the examination of water and wastewater, 20th ed. Washington DC, USA: American Public Health Association.

3. Bouwer, H. 1978. Groundwater Hydrology, McGraw-Hill Company, New York. $480 \mathrm{pp}$.

4. Colmenarejo, M. F., Rubio, A., Sanchez, E., Vicente, J., Gracia, M. G. and Bojra, R. 2006. Evaluation of municipal wastewater treatment plants with different technologies at Las-Rozas, Madrid (Spain). J. Environmental Management, 81 (4), 339-404.

5. CPHEEO, Central Public Health and Environmental Engineering Organization. 1993. Manual on sewerage and sewage treatment (2nd ed.). New Delhi: Ministry of Urban Development.

6. Eckenfelder, W. 1989. Industrial Water Pollution Control, McGraw-Hill Company, New York.

7. Erbe, V., Risholt, L.P., Schilling, W. and Londong, J. 2002. Integrated modeling for analysis and optimization of wastewater systems - the Odenthal case. Urban Water, 4(1): 63-71

8. Fatta, D., Anayiotou, S. and Papadopoulos, I. 2005. An overview of the Water and Wastewater Management Practices in Cyprus, In: IWA Specialty Conference, Wastewater reclamation and reuse for sustainability, Jeju, Korea. 
9. Coskuner, G. and Ozdemir, N.S. 2006. Performance assessment of a wastewater treatment plant treating weak campus wastewater, Int. J. Environment Pollution. 28 (1/2): 185-197 (DOI: 10.1504/IJEP.2006.010883)

10. Jamrah, A.I. 1999. Assessment of characteristics and biological treatment technologies of Jordanian wastewater, Bioprocess Engineering, 21: 331-340.

11. Karrman E. 2001. Strategies towards sustainable wastewater management. Urban Water, 3(1-2): 63-72

12. Nuhoglu, A., Yildiz, E., Keskinler, B. and Karpuzcu, M. 2004. Wastewater characterisation and performance upgrading of a domestic wastewater treatment plant: the Erzincan case, International J. Environment and Pollution, 21(5): 440456 (DOI: 10.1504/IJEP.2004.005119)

13. Tajrishy, M. and Abrishamchi, A. 2005. Integrated Approach to Water and Wastewater Management for Tehran, Iran, Water Conservation, Reuse, and Recycling, In: Proceedings of the Iranian-American Workshop, National Academies Press. pp.217-230.

14. McGhee, T. 1991. Water Supply and Sewerage; McGraw-Hill International Editions, 6th edition, New York.

15. Metcalf and Eddy Inc., (1991), "Wastewater Engineering: Treatment, Disposal and Reuse", $3^{\text {rd }}$ edition, Tata McGraw Hill Publishing Co. Ltd., New Delhi.

16. Metcalf and Eddy Inc., (2003), "Wastewater Engineering - Treatment, Disposal and Reuse", $4^{\text {th }}$ Edition, Tata McGraw Hill Publishing Co. Ltd., New Delhi.

17. Sincero, A.P. and Sincero, G.A. 1996. Environmental Engineering: A Design Approach, $4^{\text {th }}$ edition, Prentice-Hall of India Pvt. Ltd. New Delhi. 
KATHMANDU UNIVERSITY JOURNAL OF SCIENCE, ENGINEERING AND TECHNOLOGY

Table 1. Descriptive statistics of the wastewater (influent) characteristics at the inlet of Treatment plants

\begin{tabular}{|c|c|c|c|c|c|c|c|c|c|c|c|c|c|c|}
\hline & \multicolumn{7}{|c|}{ Mailasandra STP } & \multicolumn{7}{|c|}{ Nagasandra STP } \\
\hline & pH & TDS & TSS & BOD $_{(5)}$ & COD & $\mathrm{Cl}^{-}$ & $\mathrm{SO}_{4}{ }^{2-}$ & pH & TDS & TSS & $\mathbf{B O D}_{(5)}$ & COD & $\mathrm{Cl}^{-}$ & $\mathrm{SO}_{4}{ }^{2-}$ \\
\hline Count & 21 & 21 & 21 & 21 & 21 & 21 & 21 & 21 & 21 & 21 & 21 & 21 & 21 & 21 \\
\hline Mean & 7.57 & 1014.81 & 99.24 & 173.57 & 381.99 & 150.41 & 40.73 & 7.296 & 2146.19 & 468.10 & 479.52 & 789.90 & 412.67 & 41.24 \\
\hline Standard Deviation & 0.100 & 95.89 & 22.30 & 16.97 & 21.17 & 8.405 & 1.56 & 0.213 & 320.62 & 152.49 & 214.07 & 365.76 & 45.92 & 4.50 \\
\hline Minimum & 7.38 & 875 & 70 & 150 & 356 & 140.6 & 38.5 & 7.01 & 1800 & 300 & 255 & 480 & 350 & 35 \\
\hline Maximum & 7.72 & 1152 & 134 & 205 & 424 & 166 & 43.4 & 7.66 & 2850 & 766 & 850 & 1632 & 480 & 48 \\
\hline Range & 0.34 & 277 & 64 & 55 & 67.5 & 25.4 & 4.9 & 0.65 & 1050 & 466 & 595 & 1152 & 130 & 13 \\
\hline
\end{tabular}

TABLE 2. Descriptive statistics of Wastewater (effluent) characteristics at the Aeration Tank of Treatment plants

\begin{tabular}{|l|r|r|r|r|r|r|r|r|r|r|}
\hline & \multicolumn{4}{|c|}{ Mailasandra STP } & \multicolumn{5}{|c|}{ Nagasandra STP } \\
\cline { 2 - 13 } & pH & \multicolumn{1}{|c|}{ DO } & BOD $_{(5)}$ & MLSS & SVI & pH & DO & BOD $_{(5)}$ & MLSS & SVI \\
\hline Count & 21 & 21 & 21 & 21 & 21 & 21 & 21 & 21 & 21 & 21 \\
\hline Mean & 7.73 & 2.038 & 91.71 & 2877.14 & 41.58 & 7.42 & 2.20 & 171.48 & 2960.95 & 86.27 \\
\hline Standard Deviation & 0.093 & 0.397 & 9.89 & 42.56 & 0.809 & 0.149 & 0.55 & 68.64 & 72.59 & 6.28 \\
\hline Minimum & 7.49 & 1.8 & 75 & 2810 & 40.1 & 7.26 & 1.5 & 86 & 2830 & 76.92 \\
\hline Maximum & 7.82 & 3.2 & 104 & 2950 & 42.9 & 7.75 & 3.1 & 300 & 3080 & 94.59 \\
\hline Range & 0.33 & 1.4 & 29 & 140 & 2.8 & 0.49 & 1.6 & 214 & 250 & 17.67 \\
\hline
\end{tabular}

Table 3. Descriptive statistics of Wastewater (effluent) characteristics at Secondary Clarifier of Treatment Plants

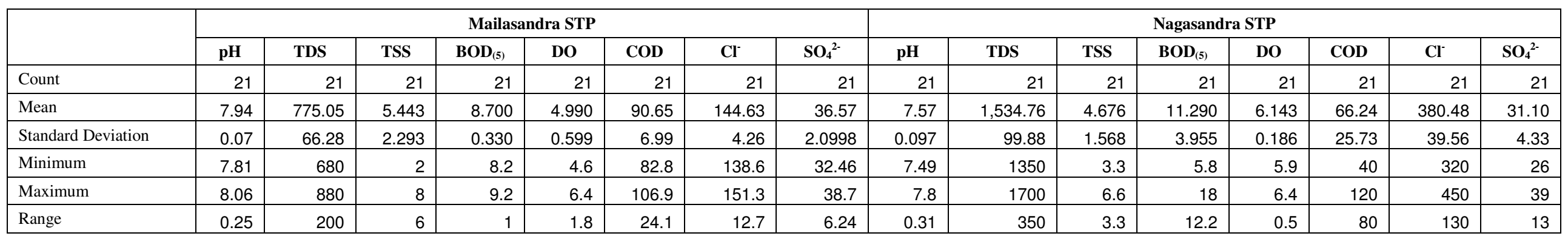


Table 4. Comparison between the COD/BOD Ratios of Treatment Plants

\begin{tabular}{|l|c|c|c|c|}
\hline \multirow{2}{*}{$\begin{array}{c}\text { COD/BOD } \\
\text { Ratio }\end{array}$} & \multicolumn{2}{c|}{ Mailasandra STP } & \multicolumn{2}{c|}{ Nagasandra STP } \\
\cline { 2 - 5 } & $\begin{array}{c}\text { Average } \\
\text { Influent }\end{array}$ & $\begin{array}{c}\text { Average } \\
\text { Effluent }\end{array}$ & $\begin{array}{c}\text { Average } \\
\text { Influent }\end{array}$ & $\begin{array}{c}\text { Average } \\
\text { Effluent }\end{array}$ \\
\hline Count & 21 & 21 & 21 & 21 \\
\hline Mean & 2.2145 & 10.411 & 1.708 & 6.037 \\
\hline Standard deviation & 0.1759 & 0.544 & 0.330 & 1.418 \\
\hline Minimum & 1.8742 & 9.767 & 0.923 & 3.357 \\
\hline Maximum & 2.4423 & 11.620 & 1.92 & 9.655 \\
\hline Range & 0.5681 & 1.852 & 0.9965 & 6.299 \\
\hline
\end{tabular}

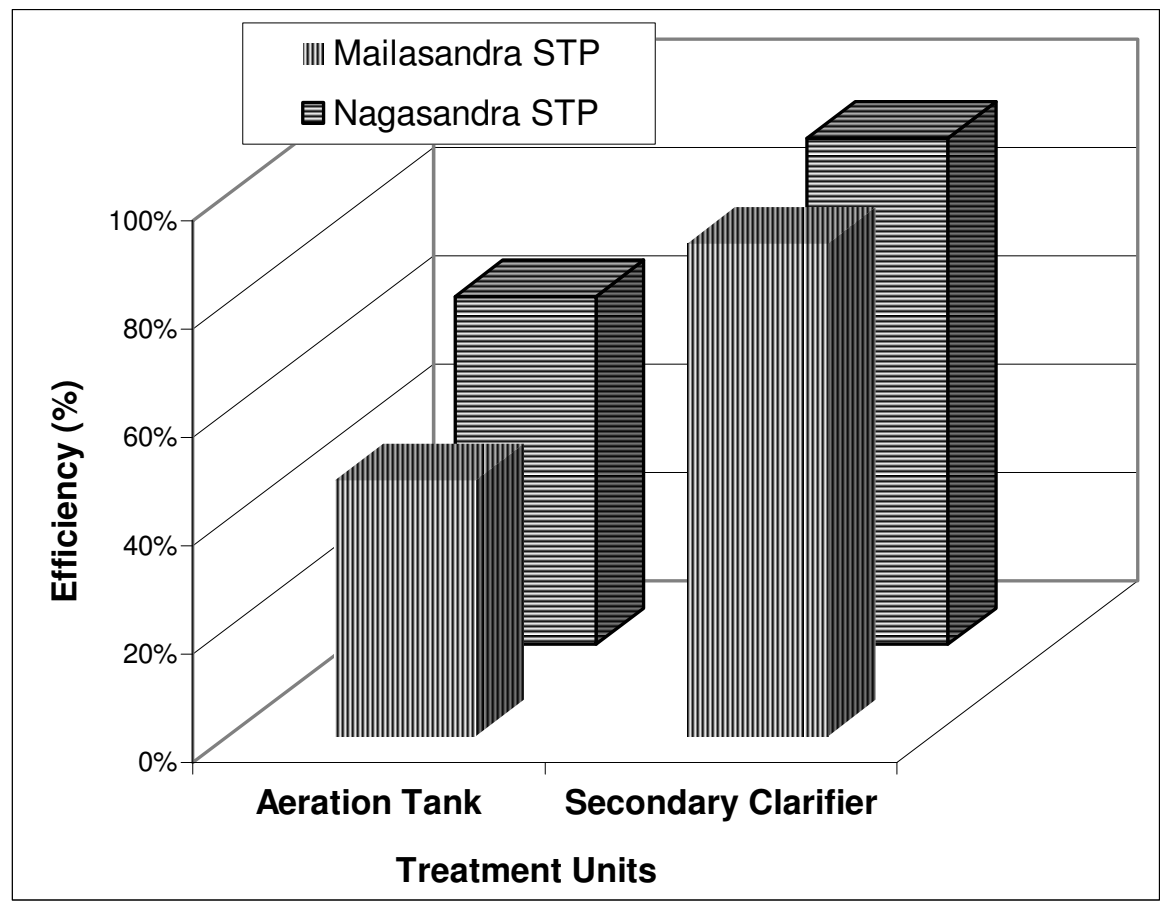

Fig 3. BOD Removal Efficiency at Mailasandra and Nagasandra treatment plants 


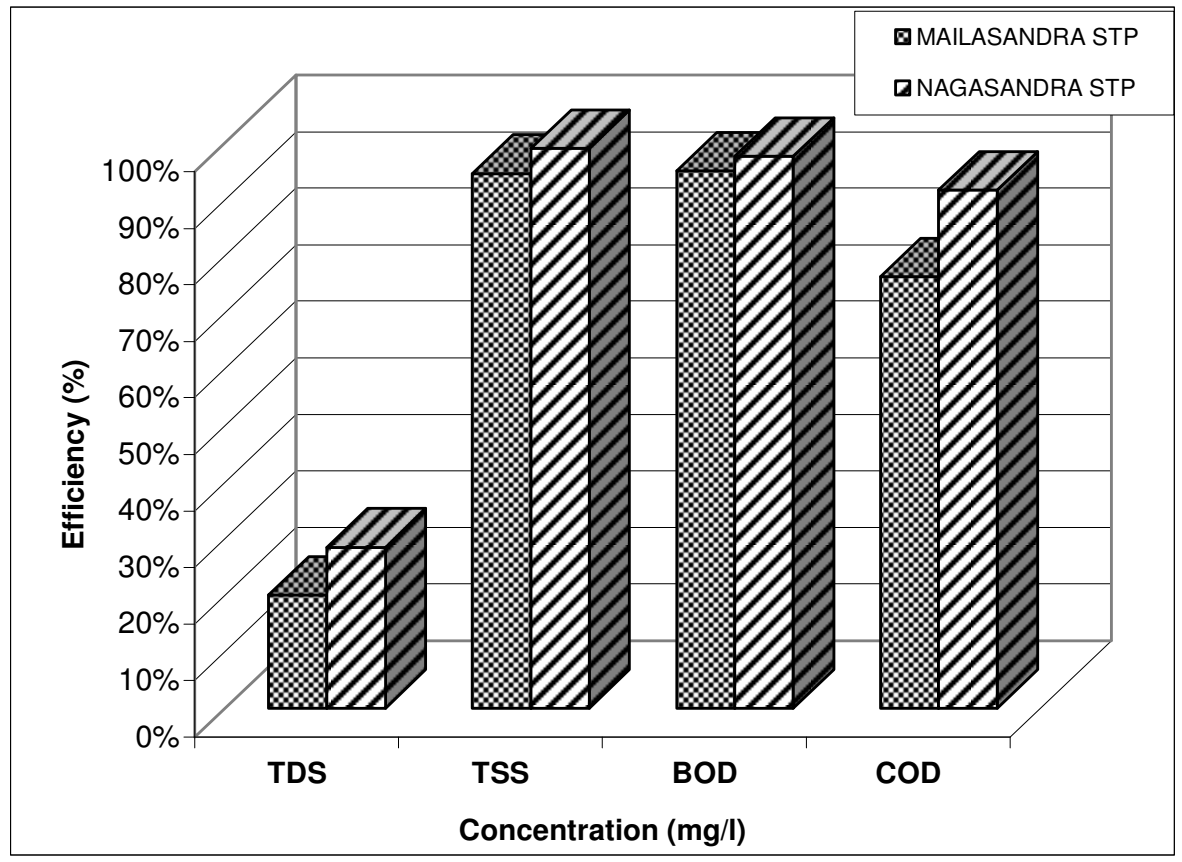

Fig 4. Comparative Account of Efficiency of Sewage Treatment Plants at Mailasandra and Nagasandra

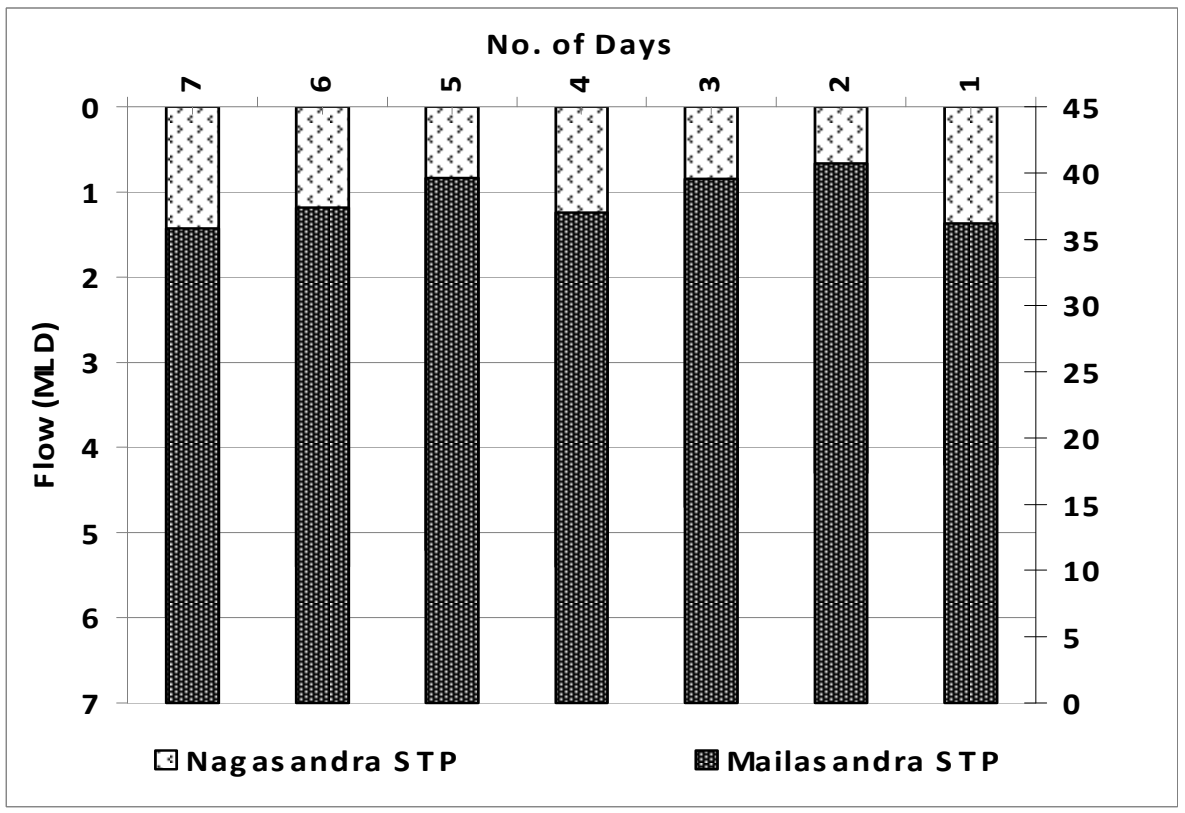

Fig 5. Variation in sewage inflow at the Mailasandra and Nagasandra STPs 